Turkish Online Journal of Qualitative Inquiry (TOJQI)

Volume 10, Issue 3, July 2019: 346-385

DOI: $10.17569 /$ tojqi.540933

Research Article

\title{
An Investigation of Student Satisfaction with an Applied Linguistics Graduate \\ Programme
}

\author{
Şakire Erbay Çetinkaya ${ }^{1}$, Selma Yılmaz ${ }^{2}$
}

\begin{abstract}
Universities are key institutions that serve to improve society and meet its needs by contributing to scientific research, technology, and social and economic welfare, helping social transformation, equipping individuals with versatile skills, to list but a few. Hence, it is of utmost importance to investigate students' satisfaction level with universities, for student opinions serve as a very important criterion to evaluate education quality and help them survive in competitive education environment. The existing literature documents several studies investigating student satisfaction in a wide array of areas. Yet, it lacks studies on satisfaction with graduate education at Applied Linguistics. Thus, the current exploratory case study aims at finding out the satisfaction level of MA and PhD students enrolled at the Applied Linguistics programme of a public higher education institution in Turkey. A qualitative inquiry was conducted via individual and semi-structured face-to-face interviews with 13 $\mathrm{MA}$ and $6 \mathrm{PhD}$ voluntary students at the programme. The findings gathered from a qualitative content analysis show that the programme was found efficient due to high education quality thanks to wellequipped teaching staff, good services, and encouragement to produce academically. Yet, assessment and evaluation and academic supervision were found as two aspects to be improved. In the end, programme coordinators are provided ways to enhance both education and service quality of similar programmes.
\end{abstract}

Keywords: Graduate education, satisfaction, $\mathrm{PhD}, \mathrm{MA}$, education, quality

\footnotetext{
${ }^{1}$ Asst.Prof.Dr., Karadeniz Technical University, Faculty of Humanities, Department of English Language and Literature, sakireerbay@ ktu.edu.tr, https://orcid.org/0000-0003-2594-1205

${ }^{2}$ Graduate Student, Karadeniz Technical University, Faculty of Humanities, Department of English Language and Literature, selka_80@ hotmail.com, https://orcid.org/0000-0002-5985-7629
}

Received: 16.03.2019, Accepted: 30.07.2019 


\title{
Bir Lisanüstü Uygulamalı Dilbilim Programına Yönelik Öğrenci Memnuniyeti Araştırması
}

\begin{abstract}
$\ddot{\mathbf{O z}}$
Yüksek öğrenim kurumları bilimsel araştırma, teknoloji ve sosyal ve ekonomik refaha katkıda bulunarak, sosyal dönüşüme yardımcı olarak ve bireyleri çeşitli becerilerle donatarak toplumu geliştirip ihtiyaçlarını karşılayan önemli oluşumlardır. Bu yüzden bir nevi üniversite müşterisi olan öğrencilerin memnuniyetini araştırma son derece mühimdir çünkü öğrenci fikirleri eğitim kalitesini değerlendirmede ve kurumun rekabetçi eğitim ortamında hayatta kalabilmesi için çok önemli bir ölçüttür. Var olan alan yazın çeşitli programlarda öğrenci memnuniyetini irdeleyen pek çok çalışmayı özetlemektedir. Ancak bu alan yazında lisansüstü uygulamalı dilbilimi programlarına yönelik memnuniyet çalışmaları eksiktir. Bu yüzden mezkûr durum çalışması, Türkiye'deki bir devlet üniversitesinin uygulamalı dilbilimi programına kayıtlı yüksek lisans ve doktora öğrencilerinin memnuniyet derecesini araştırmayı hedeflemektedir. $\mathrm{Bu}$ nitel araştırma kapsamında gönüllü 13 yüksek lisans ve 6 doktora öğrencisi ile bireysel ve yarı yapılandırılmış yüz yüze mülakatlar gerçekleştirilmiştir. Nitel içerik analizi sonucunda elde edilen bulgular, programın donanımlı öğretim kadrosu, tatmin edici hizmetler ve akademik üretimi teşvik sayesinde kaliteli yüksek eğitim sunması hasebiyle çoğunluk tarafından etkili bulunduğunu göstermektedir. Ancak, ölçme değerlendirme ve akademik danışmanlığın iyileştirilmeye ihtiyaç duyulan iki önemli alan olduğu görülmüştür. Çalışma sonunda program koordinatörlerine benzer programların eğitim ve hizmet kalitesini artırma konusunda öneriler verilmektedir.
\end{abstract}

Anahtar Sözcükler: Lisansüstü eğitim, memnuniyet, doktora, yüksek lisans, eğitim, kalite 


\section{Introduction}

Higher education in a large spectrum of disciplines is significant for a society as it is supposed to contribute to scientific research, economic productivity, culture enhancement, creativity, to list but a few. These institutions offer education that helps effective human resources planning in industrialised communities to meet social needs, ensure production (Bozan, 2012; İçli, 2001), save and enhance both local and cultural and universal cultural heritage (Batmaz, Öztürk, Vardar, Yanık, Yarman \& Yazıc1, 2011; Tekin, 2007), and equip individuals with versatile skills including creativity, critical thinking, analytic thinking, productivity, and problem solving (Oğuz, 2004; Öztemel, 2013).

Higher education institutions started to serve as a basis for economic development and information generation for large masses rather than solely elite classes particularly after the Second World War (Göksu, 2015) at not only local but also global levels (Erdem, 2013). Determining student expectations, opinions, and satisfaction level is of utmost importance to evaluate quality of higher education institutions and thus helps their survival. The existing literature documents several studies on undergraduate and graduate program evaluation from student perspectives in a wide variety of fields covering teaching English (Hernandez, 2009), special education (Moses (2008), administration and economy (Al-Dulaimi, 2016), business (Mai, 2005), health/nursing (Hahessy, Burke, Byrne, Farrley, Kelly, Mooney \& Meskell, 2014), public policy, affair, and administration (Bright \& Graham, 2016), pharmacy (Chumney \& Ragucci, 2006), music (Serenko, 2010), to list just a few. Turkish scholars have not shut their eyes to the importance of measuring students' satisfaction: education science (Sümen \& Çağlayan, 2013; Yılmaz, Tonga \& Çakır, 2017), primary education (Özçetin \& Gök, 2017; Şahin, 2009), nursing (Özdelikara \& Babur, 2016), Turkish teaching (Kara, 2017), office management and executive assistance (Ay \& Koç, 2014), computer education and instructional technologies (Tatl1, Kokoç \& Karal, 2011), business administration (Erdoğan \& Bulut), to list but a few.

Despite these satisfaction studies in various fields, qualitative exploratory case investigations on English teaching covering both Master of Art (MA, henceforth) and Philosophy of Doctorate Education ( $\mathrm{PhD}$, henceforth) programmes together to draw a holistic picture are rare. 
Furthermore, the current ones mostly chose quantitative research designs, i.e., surveys, to measure satisfaction level of a high number of students (see, for instance, Al-Dulaimi, 2016; Özçetin \& Gök, 2017; Mai, 2005). Yet, explorative studies with in-depth and open-ended questions rather than questionnaire surveys are needed to dig deep into the answers of students. Thus, as a response to the calls to fill in this research niche, the current exploratory case study was designed to investigate to what extent $\mathrm{MA}$ and $\mathrm{PhD}$ students enrolled at an Applied Linguistics graduate education programme find the programme efficient regarding its education and service quality. Besides, the current study is believed to be important as it meets the originality criteria of Blaxter, Hughes and Tight (2010) in social sciences. It is original as the researchers were the first one to investigate student satisfaction with MA and $\mathrm{PhD}$ together in the aforementioned programme, and they obtained new information written for the first time via a self-devised data gathering instrument. Also, the findings could stimulate other researchers to conduct parallel studies and contribute to the existing literature by comparing and contrasting their findings. Last but not least, such small-scale explorative studies are of paramount importance to help higher education institutions develop compensating strategies to survive in competitive education environment, reform to overcome deficiencies, attract new comers and retain the current ones (Al-Dulaimi, 2016; Alves \& Raposo, 2007; Durmaz, 2011; Koshkin, Rassalov \& Novikov, 2017; Serenko, 2010; Tan \& Kek, 2004).

\section{Review of Literature}

\section{Higher Education}

Historically speaking, University of Humboldt first offered the degree of $\mathrm{PhD}$ in return for thesis defence of an original research study and has become a model for universities as the centres of modern science, research, and publication. In Ottoman period, Darulfünun stood for university, and it took about half century for universities to be transformed into researchoriented institutions in Turkey, for doctoral programmes made no progress until 1946. However, in accordance with the law (No: 4936), Turkish universities were granted with legal autonomy, and thesis study became obligatory in that candidates are supposed to conduct an authentic investigation with a systematic research design and defend it in front of a scientific committee in pursuit of a $\mathrm{PhD}$ degree, and scientific research becomes compulsory for professors in academic area (Giorgetti, 2014). 
In Turkey, universities with an important and respectful position in society due to their knowledge, economy, culture, and generation-related functions offer two degree education under the guidance of Council of Higher Education. The first one is undergraduate education that covers both Associate's degree of education and Bachelor Art degree education (BA). While the former aims at cultivating qualified work force on a specific vocational area in 2 years, BA equips students with a large variety of capacities in eight semesters except for dentistry and veterinary programmes with 5-year education and 6-year medicine programme (Official Gazette, 1981).

The second degree education is graduate education that should be understood as formal training process covering master and doctoral education under the responsibilities of universities (Karakütük, 1989). It undertakes a significant role in the development of a country and further improvement in scientific and technological disciplines (Koğar \& Sayın, 2014; Ören, Y1lmaz \& Güçlü, 2012; Sevinç, 2001). In another word, it holds a strategic position both in generating and spreading information and transferring it into life as well as ensuring qualified work labour force (Bozan, 2012). Universities in Turkey offer two kinds of MA education: MA with thesis and without thesis. MA with thesis aims at equipping students with abilities to use various research methods and techniques to access, compile, interpret, and evaluate data. The MA degree candidates are supposed to complete certain credits and seminar courses. They are appointed an academic supervisor under whose supervision they complete their MA thesis and take their degree after a successful thesis defence in the presence of a jury. On the other hand, in the graduate programme without a thesis, candidates are equipped with knowledge in professional fields and learn how to utilise the existing knowledge by completing certain credits and course projects (Official Gazette, 2016). Doctoral degree programmes aim at equipping candidates with intellectual autonomy to produce new scientific knowledge. Holders of a PhD degree are supposed to conduct independent research for responding to demands regarding economic and technological growth (Anderson, Cutright, \& Anderson, 2013; Ersoy, 2015; Özmen \& Güç, 2013, Varış, 1972). 


\section{The Concept of Satisfaction and Its Importance}

Satisfaction in general should be understood as a reaction or feeling towards an offered product or service (Athiyaman, 1997; Giese \& Cote, 2002). Similarly, Kotler and Keller (2012) note that satisfaction should be understood as personal judgement regarding expectations.

Particularly, student satisfaction refers to the state that comes about when students' various needs are responded by education institutions (Altaş, 2006; Uygun \& Yelken, 2017). According to Aydemir (2016), student satisfaction is influenced by various elements including education quality, library service, transportation, consultancy, accommodation, food, social activities, and employment opportunities for alumni supported by the university.

It is of paramount importance to explore student satisfaction in universities for a number of reasons. Thanks to such investigations, university administrations can develop strategic plans to overcome their deficiencies (Al-Dulaimi, 2016; Durmaz, 2011). These student reports help universities attract potential students and retain the existing ones, thereby contributing to their attempts to be superior in competitive education sectors (Mehdipour \& Zerehkafi, 2013; Tan \& Kek, 2004).

From another perspective, Mwiya et al. (2017) highlight that student satisfaction is regarded vital due to advisability and reputation. When they are satisfied, they talk about the institution positively and suggest it to other people including their friends and relatives. Furthermore, their satisfaction encourages them to come back there to have further degrees.

\section{A Slice of Previous Research}

A great number of scholars from different education contexts have investigated to what extent students from diverse departments are pleased with their institutions (see, for instance, AlDulaimi, 2018; Bright \& Graham, 2016; Chumney \& Ragucci, 2006; Erichsen, Bolliger, \& Halupa, 2014; Jalali, Islam, \& Ariffin, 2011; Kashan, 2012; Mai, 2005; Moses, 2008, to list but a few). To illustrate, Hernandez (2009) investigated satisfaction level of 41 MA holders in teaching English as a foreign language programme at University of Costa Rica with a questionnaire study. A majority of the participants were found satisfied with what they learned regarding teaching English classes, planning courses, organising teaching classes, planning 
courses, and developing materials. However, several weak areas were identified, teaching of grammar and pronunciation, including language assessment. The participants reported that the programme did not offer enough knowledge about language assessment, and the teaching of grammar and pronunciation. However, they were unhappy as the programme did not provide them sufficient language, and thus they were having difficulties with grammar and pronunciation during teaching English. Also, the information that the department offered them about needs analysis and English for Specific Purposes, course design and practicum, and foreign language learning theories was reported to overburden them, and only some employed the teaching methods they had learnt during their education. Also, it was verbalised that they were not adequately taught how to utilise technological devices in language classes.

Turkish scholars have not shut their eyes to the need to conduct satisfaction studies for programme improvement (see, for instance, Kara, 2017; Kaya \& Engin, 2007; Özçetin \& Gök, 2017; Özdelikara \& Babur, 2016; Sümen \& Çağlayan, 2013; Şahin, 2009, to list but a few). To illustrate, in a recent study Y1lmaz et al. (2017) investigated the satisfaction level of the graduate students in the institution of educational sciences of a long-established public university in Turkey within the scope of instructors, advisors, managers, the graduate education process, and the physical conditions with a descriptive survey. The findings show that female students were more satisfied with lecturers, and this satisfaction is much higher than those in the $\mathrm{PhD}$ programme. They also found that satisfaction level with advisor, the graduate education program, physical facilities, and management was not affected by gender. What is more, it was articulated that doctoral students had more academic attainments than master students. Thus, it was suggested that administrative staff should dwell on this issue, and measures should be taken to encourage academic attainments of master students, for all MA students may not have the chance to continue their graduate education in $\mathrm{PhD}$. The graduates who were working as academician were found less satisfied with the instructors, and physical conditions than the teachers, and overall satisfaction of teachers with the graduation education was higher compared to the academicians. The researchers commented that academicians had superior-subordinate relationship with the instructors, and they might consider some aspects other than education. . Hence, satisfaction was concluded to be affected by professional experiences rather than gender, program, and occupation.

Overall, the existing literature has documented several related studies. Yet, these earlier studies either investigated student satisfaction generally at one level (BA, MA, or $\mathrm{PhD}$ ) or opted for a 
quantitative research design and conducted large-scale surveys. However, the current study aimed at filling the research niche in that it qualitatively investigated the issue from a holistic perspective, i.e., student satisfaction with not only MA but also $\mathrm{PhD}$ programme. The current study aimed at investigating the satisfaction level of the students in the graduate education programme of a large-scale public university with both the education and service quality. To this end, the following major and minor research questions were devised:

1. Are the MA and $\mathrm{PhD}$ students satisfied with the graduate education offered by the institution?

1.1. Are the students satisfied with education/program quality?

1.1.1. Are they satisfied with supervisor? Why/Why not?

1.1.2. Are they satisfied with instructors? Why/Why not?

1.1.3. Are they satisfied with curriculum? Why/Why not?

1.1.4. Are they satisfied with course content? Why/Why not?

1.1.5. Are they satisfied with course teaching methods? Why/Why not?

1.1.6. Are they satisfied with assessment and evaluation of exams? Why/Why not?

1.1.7. Are they satisfied with learning climate of classroom? Why/Why not?

1.1.8. Are they satisfied level with academic attainments of program? Why/Why not?

1.2. Are the students satisfied with service quality?

1.2.1. Are they satisfied with administrative services? Why/Why not?

1.2.2. Are they satisfied with physical facilities? Why/Why not?

2. Are there any suggestions to improve the program?

\section{Methodology}

To answer the research questions above a qualitative methodology was opted for. The current study shows the features of qualitative research that Bogdan and Biklen (2007) list. The study could be entitled as naturalistic in that the practitioner researcher and the student one spent time 
in the natural setting, i.e., the university, to gather the data. Besides, the desire to describe not reduce the richness of data encouraged the researchers to indicate this richness with excerpts taken from the data. Last but not the least, the present study is qualitative in that it paid much attention on meaning by analysing the $\mathrm{MA}$ and $\mathrm{PhD}$ students' perspectives, feelings, and attitudes.

An exploratory case study was conducted to gather in-depth data as one of the most preferred research methods with the qualitative methodology (Queirós, Faria, \& Almeida, 2017). Case studies should be understood as research attempts to develop deeper understanding and description of single instances with careful analysis in unique contexts rather than numerical generalizations (Cohen, Manion \& Morrison, 2007; Yin, 2009). It is one of the research methodologies appropriate for educational research, and in this education case it enabled the researchers to provide an exploration into the students' satisfaction with the programme and their reasons. Also, the desire of the researchers to seek for in-depth exploration, quality, and data richness contrary to the earlier related studies that mostly adopted survey methodology and focused on quantity necessitated a case study research design. The investigation of attitudes and feelings "invite(s) the use of in-depth case studies with qualitative data" as Denscombe (2010, p. 165) rightly notes. Besides, such case studies are also believed practical in that the information that could be applied by practitioners (Koshkin, Rassalov \& Novikov, 2017; Serenko, 2010).

The case of the current research was the applied linguistics graduate programme of a public higher education institution in Turkey. Semi-structured individual in-depth interviews were utilised to gather the qualitative data that could help explore the world of graduate students and gain their experiences. This specific education case was chosen as the practitioner researcher has been working at the institution for 9 years, and the student researcher is an active student having close contact with students from all levels. This enabled them to gather rich data easily.

Despite the well-documented advantages of this research design, its subjective nature in data analysis and reporting (Cohen et al., 2007) is one of its limitations. To overcome this limitation, the two researchers coded and categorised the data separately, and then they compared and contrasted their findings. Another criticism case study has received is the small number of subjects, which avoids making scientific generalisation. However, exploring the feelings of the 
students in this single specific case rather than generalising from it was the ultimate aim of the current study.

\section{Setting and Participants}

The current study was conducted at a Turkish public university, which has a large number of graduate programs, and the MA and PhD programme in Applied Linguistics is one of them. The graduate education programme is housed by the Department of Western Languages and Literature, which grants undergraduate students with BA degree in the field of English Language and Literature and graduate ones with MA degree on Applied Linguistics and $\mathrm{PhD}$ degree on English Language and English Literature. The staff includes 2 associate professors, 7 assistant professors, 2 lecturers, 4 instructors, and 3 research assistants. The $\mathrm{MA}$ and $\mathrm{PhD}$ programme offers several course, including Scientific Research and Publication Ethics, Sociolinguistics, Qualitative Research, Literature and Language in Education, Statistical Analysis, Media Studies Language, Text and Context, Pragmatics, Education of Scientific Research and Project Preparation, The Rise and Development of the Novel, Research in Social Science, Seminar, MA Thesis, Syllabus Design, Culture and History, Semantics and Pragmatics, Qualitative Research Methods, Educational Psychology, Using Corpus for Language Pedagogy, Exploring the Language of Drama, Special Issues in Research Methods, and PhD Thesis. The department also encourages both undergraduate and graduate students to have classes from local and foreign universities via exchange programmes like Erasmus, Mevlana, and Farabi.

This program offered by the Institute of Social Sciences is hosted by the Department of English Language and Literature founded in 1999. The graduate education programme offers degrees for Applied Linguistics (MA), and English Literature (PhD) and English Language (PhD). The program has been running for over 18 years. The MA programme started in 2001-2002, and the $\mathrm{PhD}$ programme was initiated in 2008-2009 education term. Although this graduate programme has been offering these degrees, there is no study examining the programme, namely student satisfaction.

The participants of the current study were chosen with convenience sampling which serves "an excellent means of obtaining preliminary information about some research question quickly 
and inexpensively" (Berg, 2004, p. 35). 19 participants $(\mathrm{F}=10 ; \mathrm{M}=9)$ voluntarily accepted to be interviewed. The demographic information related to the participants is provided in the following table.

Table1

Demographic Profile Data of the Participants

\begin{tabular}{|c|c|c|c|c|c|c|c|}
\hline Participant & $\begin{array}{l}\text { current } \\
\text { Profession }\end{array}$ & Working Place & Degree & Gender & Age & Homeland & $\begin{array}{l}\text { Interview } \\
\text { Date }\end{array}$ \\
\hline Seyma & Lecturer & State University & $\mathrm{PhD}$ & 우 & 34 & Trabzon & 17 Jan. 2018 \\
\hline Zeliha & $\begin{array}{l}\text { Research } \\
\text { Assistant }\end{array}$ & State University & MA & q & 24 & Rize & 22 Jan. 2018 \\
\hline Sude & $\begin{array}{l}\text { Research } \\
\text { Assistant }\end{array}$ & State University & $\mathrm{PhD}$ & q & 26 & Kayseri & 6 Feb. 2018 \\
\hline Gizem & $\begin{array}{l}\text { English } \\
\text { Teacher }\end{array}$ & Private College & MA & q & 36 & Trabzon & 6 Feb. 2018 \\
\hline Tugce & Lecturer & State University & $\mathrm{PhD}$ & q & 35 & Trabzon & 16 Feb. 2018 \\
\hline Kemal & Lecturer & State University & MA & ๙ & 37 & Trabzon & 19 Feb. 2018 \\
\hline Cetin & Lecturer & Private University & MA & 入 & 27 & Giresun & 26 Feb. 2018 \\
\hline Hayri & Translator & Private Sector & MA & त & 23 & Palestine & 26 Feb. 2018 \\
\hline Ali & $\begin{array}{l}\text { English } \\
\text { Teacher }\end{array}$ & $\begin{array}{l}\text { Ministry of } \\
\text { Education }\end{array}$ & MA & o & 27 & Trabzon & 1 Mar. 2018 \\
\hline Ebru & $\begin{array}{l}\text { English } \\
\text { Teacher }\end{array}$ & Private College & MA & q & 37 & Trabzon & 3 Mar. 2018 \\
\hline Busra & Lecturer & State University & MA & q & 43 & Trabzon & 6 Mar. 2018 \\
\hline Zilan & Lecturer & State University & MA & 우 & 30 & Trabzon & 7 Mar. 2018 \\
\hline Yusuf & Lecturer & State University & $\mathrm{PhD}$ & 入 & 34 & Rize & 7 Mar. 2018 \\
\hline Ebrar & Lecturer & State University & MA & 우 & 30 & Ordu & 8 Mar. 2018 \\
\hline Hamit & Lecturer & State University & MA & ๙ & 27 & Trabzon & 12 Mar. 2018 \\
\hline Mustafa & $\begin{array}{l}\text { Research } \\
\text { Assistant }\end{array}$ & State University & MA & $\hat{0}$ & 25 & Erzurum & 16 Mar. 2018 \\
\hline Umut & $\begin{array}{l}\text { English } \\
\text { Teacher }\end{array}$ & $\begin{array}{l}\text { Ministry of } \\
\text { Education }\end{array}$ & MA & $\lambda^{\lambda}$ & 24 & Sivas & 19 Mar. 2018 \\
\hline Tarık & Lecturer & $\begin{array}{l}\text { State } \\
\text { University }\end{array}$ & $\mathrm{PhD}$ & त & 38 & Samsun & 04 May 2018 \\
\hline Zennure & $\begin{array}{l}\text { Research } \\
\text { Assistant }\end{array}$ & State University & $\mathrm{PhD}$ & q & - & - & 17 May 2018 \\
\hline
\end{tabular}


As is seen above, 19 participants are from diverse provinces of Turkey although most come from Trabzon. Only one is foreign, i.e., from Palestine. Age range is large in that ages start from 24 and go on till 43.

\section{Data Gathering and Analysis}

Semi-structured individual in-depth interviews were opted for to investigate the participants' satisfaction level and dig deep into their reasons. This technique allows researchers to investigate participant' insights and feelings about a specific program, case, or notion thoroughly (Boyce \& Neale, 2006; Queirós et. al, 2017). Besides, via in-depth interviews, it is possible to check answers, ask further questions, and obtain comprehensive information on the subject (Queirós et. al, 2017; Qu \& Dumay, 2011). In this case, semi-structured interview was utilised as it enabled the researchers to design a series of questions, change the sequence of them if needed, and ask further questions in response to the replies of the participants. What is more, it was opted for as it is less intrusive in people's lives in that the process may take up much time in organisational settings such as education institutions, otherwise (Bryman, 2004). Here, as most of the participants have been working as academic staff, the researchers did not want to violate the rhythm of responsibilities and thus chose interview at their best convenience.

Two apparatus, Samsung brand, were utilized in the process as tape recorder so as to tolerate data loss in case of possible malfunction. Once the data were gathered, they were stored in a file to be transcribed. In order to eliminate the language related-barriers, collect rich data, and create authentic atmosphere in communication, the interviews were conducted in Turkish. The participant whose mother language was Arabic requested to speak in English as a second language. However, from time to time both parties code-switched from English to Turkish as both the interviewer and the interviewee were fairly fluent in English. As two participants (one male and one female) openly stated their discomfort with being audio recorded, they were offered the chance to respond in a written mode at their best convenience and send the written self-reports to the researchers. The data were gathered in five months, starting in January 2018 and finishing in May 2018. It was challenging to get participants' best convenience. Further the duration of interviews ranged from 15 minutes to 49 minutes. 
The qualitative data gathered thorough individual interviews were analyzed by means of content analysis which is a popular method among social scientists to understand people's practices by analysing textual formats of various texts including TV programs, adds, films and news, and scripts gathered from interviews and making interpretations (Elo \& Kyngas, 2008; Macnamara, 2005; Yan, McCracken \& Crowston, 2014).

All of the interviews were transcribed verbatim, a suitable format, soon after the meetings and printed out with the aim of revising and increasing familiarity of the transcribed texts. Following this transaction, the data on narrative text were taxonomically classified and coded to draw meaning, i.e., codes were used as means of inference (Gocer, 2010). Coding is "the process of organising the data into chunks of information and writing a word that represents a category in the margin" (Theron, 2015, p.7). In this case, coding is useful to indicate frequency of occurrences on the transcripts to constitute categories and sub-categories. In content analysis, basically three steps were followed: data organising, data reduction, and data representing (Creswell, 2007). Before starting to analyse the data, the researchers converted the audio data into text data via verbatim transcription. Then they separately looked through this data several times, identified the codes, and created the categories. Later, they compared and contrasted their draft analysis. Lastly, they tabulated their findings and picked up excerpts from the interviews, which are "more illuminative and direct" than the researchers' own words (Cohen et al., 2007).

In the first step of data gathering, some of the participants were visited in their offices, and some were called up since they lived in different cities to have appointment in the best convenient time and place and inform the participants about the study. It was a long and challenging process to have the participants' convenience due to fact that they had to deal with many things simultaneously such as thesis writing, article writing, lecturing, conferencing, and having other academic tasks in addition to their family responsibilities. Also, prior to appointment time most of the participants whose consents were obtained were reminded via messages. In essence, voluntary participation was grounded in the study, i.e., considering their willingness to be interviewed. Before the interviews, the participants were informed about ethical considerations, and they were politely asked for permission of voice record. Additionally, it was emphasized that their contribution would mean a lot to the study. During the interview, when the participants were reluctant to respond any addressed question, they were allowed to leave it unanswered, i.e., participants could skip any 
question they were unwilling to answer. To stick to ethical principles, personal identities of the participants were excluded in the study to ensure anonymity. Hence, the participants were given nicknames. In the final step, they were sincerely thanked for valuable contribution and offered kindly chocolate as incentive. It is also worth to note no deception was included in the methodology of study.

The researchers attempted to ensure validity as the touchstone of research through some steps. First, inspired by some studies documented in the related literature (see Hernandez, 2009 and Y1lmaz et al., 2017), the researchers devised several interview questions to investigate student satisfaction with both education and service quality of the aforementioned programme. However, for the content validity of the data gathering instrument, the researchers prepared the final version of the prompts taking time and motivation of the participants into account. They also paid much attention to whether the questions cover these two domains from all aspects, i.e., education and service. Both of the researchers worked on them from September 2017 to January 2018. They translated them into Turkish and worked on the translations separately and then together. To increase the reliability, validity, and practicability of the interview questions, i.e., to identify the possible problems with wording and check timing, the first researcher asked for the opinions of her thesis supervision students. After getting their feedback, they prepared the final version of the questions.

Second, the use of multiple researchers is another way of ensuring internal validity. This investigator triangulation (Denzin, 1970, as cited in Cohen et al., 2007) enabled the researchers to design the instrument, identify codes and categories independently in data analysis and later compare and contrast the findings to reach a total agreement. Also, they improved the validity of the qualitative data gathered with interviews by being honest in data representing and documenting the data in its depth and richness via codes, categories, qualities and excerpts taken from interviews without limiting the data to solely numbers (Cohen et al., 2007). During the interviews the researchers encouraged the participants give detailed answers and utilised bridging questions and paraphrase to ensure the correct understanding, and in while reporting their data, they supported the research qualities with detailed respondent excerpts, for "in-depth responses of individuals secure a sufficient level of validity and reliability" (Agar, 1993, as cited in Cohen et al., 2007, p. 135) in qualitative research. 
Besides, the researchers tried to ensure the transferability of their findings by providing a thick description of research, i.e., every research details about data gathering, analysis, "so that others can decide the extent to which findings from one piece of research are generalizable to another situation" (Schofield, 1990, as cited in Cohen et al., 2007, p. 137). In order to address credibility, the researchers utilised peer debriefing (Lincoln \& Guba, 1985, as cited in Cohen et al., 2007) in that the first researchers asked for the opinions of two colleagues, holding MA and $\mathrm{PhD}$ degrees in Applied Linguistics, about general methodology. Besides, another expert colleague in the same institution detected some general errors in the data analysis, i.e., overemphasis on quantification of the codes, and therefore the researchers paid much attention to qualities and their support with excerpts in the final version of the report rather than quantifying their findings. Also, the researchers tried to ensure credibility via member checking in that the interviewer paraphrased the responses to check correct understanding and offered the interviewees to add further information.

The present study endeavoured to relieve the participants and elicit honest and detailed answers. The researchers were aware of the possibility that the participants might feel hesitant to answer the questions due to the risk of identification and thus might not voice their real feelings. They tried to control this issue by creating a comfortable interview environment, offering them interview options, developing a rapport with them, allocating enough time to respond, ensuring confidentiality and anonymity, and offering chance to learn research results in the future. The researchers tried to create a comfortable environment by asking the participants where and when to be interviewed. While most chose to be interviewed in their own office to avoid possible interruptions, some opted for the school cafeteria as they came to school once a week, it was convenient for them, and they could avoid wasting time due to their hectic professional and academic life. Besides, to relieve the participants the researchers offered them options. As two of them voiced their discomfort in being audio recorded, they were asked to answer the questions by writing their answers on paper at home and sending the written reports to the researchers later. Besides, the researchers tried to establish a good rapport with the participants by informing them that they were investigating their satisfaction as a BA graduate project and they were going to present the findings in an international conference in Sinop, a Turkish province along the Black Sea situated on the most northern edge of Black Sea. This transparency was believed to help them trust the researchers and be honest with their answers (Booth \& Booth, 1994). They also tried to reduce their possible anxiety by making 
small talks about their life, studies, and the department. They also allowed time for responding and waited patiently when they were silent as these are believed to ensure honest answers (Elmir, Schmied, Jackson \& Wilkes, 2011). Furthermore, at the very beginning of the process the participants were ensured confidentiality and anonymity by not asking any personal information and promising to give nicknames to them in the report. Lastly, they were offered chance to learn research results by asking the contact information of those who wanted to learn more.

The methodology part should conclude by clarifying the roles of the researchers. The first researcher working as a both researcher and lecturer at the institution for 8 years is an expert in Applied Linguistics, and thus she guided the whole process from reading to reporting and gave the right methodological decisions about data gathering, analysis, and reporting. They read and internalise the existing body of literature together. The second researcher studying at the department for 4 years took an active role in that she got appointment from the participants and conducted most of the interviews at the best convenience of the participants. However, the first researcher made contact with the participants and asked whether they were willing to be interviewed. After the researchers transcribed the data, they analysed it separately, compared and contrasted their findings, and prepared a reader-friendly research report at the end.

\section{Findings and Discussion}

The results of the content analysis are presented theme by theme and supported with tables in a reader friendly way. Besides, excerpt taken from interviews are utilised to support each theme.

\section{Satisfaction with Education Quality}

In the current study education quality should be understood as a concept with diverse parameters, including supervisor, instructor, curriculum, course content, teaching methods, assessment and evaluation, learning climate, and academic attainments. The related findings are presented one by one below. 
Most of the participants seemed to be highly satisfied with their supervisors/advisors as the positive codes exceed the negative ones ( $n=74 ; 12$, respectively). The following table quantify the related findings.

Table 2

Encoded Participant Comments about Supervisors/Advisors

\begin{tabular}{|c|c|c|c|}
\hline Satisfaction Codes & $\mathrm{f}$ & Dissatisfaction Codes & $\mathrm{f}$ \\
\hline Being specialist in field & 11 & Not sharing enough time for students & 2 \\
\hline Having good communication with students & 9 & Having really busy schedule & 3 \\
\hline Having pedagogical competence & 8 & Not giving detailed supervisor feedback & 2 \\
\hline Guiding students in thesis writing well & 7 & Supervising too many students together & 2 \\
\hline Being expert in research/academic issues & 6 & $\begin{array}{l}\text { Having difficulty in accessing supervisor } \\
\text { whenever they want }\end{array}$ & 1 \\
\hline Supervising students about various issues & 5 & Getting feedback late & 1 \\
\hline Providing needed feedback and guidance & 3 & Not offering orientation training & 1 \\
\hline Being accessible whenever students want & 3 & & \\
\hline Providing expert opinion for students' works & 2 & & \\
\hline Getting highly detailed feedback & 2 & & \\
\hline Being understandable & 2 & & \\
\hline Being student-friendly & 2 & & \\
\hline Having open vision & 1 & & \\
\hline Being meticulous & 1 & & \\
\hline Behaving well & 1 & & \\
\hline Publishing in prestigious journals & 1 & & \\
\hline Having academic conversation out of class & 1 & & \\
\hline Providing encouragement about academic tasks & 1 & & \\
\hline Valuing students work & 1 & & \\
\hline Encouraging critical thinking & 1 & & \\
\hline Sharing his own sources with students & 1 & & \\
\hline $\begin{array}{l}\text { Capable of making a topic understandable for } \\
\text { students }\end{array}$ & 1 & & \\
\hline Allocating much time for students & 1 & & \\
\hline Providing hints about academic writing & 1 & & \\
\hline Showing required care and attention & 1 & & \\
\hline Guiding students how to reach sources & 1 & & \\
\hline \multirow[t]{2}{*}{ TOTAL } & 74 & & 12 \\
\hline & 86.04 & & 13.95 \\
\hline
\end{tabular}


The fact that supervisors are equipped with knowledge seems the basic reason for high satisfaction with the programme. The participants admired their supervisors as they were believed to have deep subject knowledge, pedagogical knowledge, expertise in their field, and the capacity to supervise their students about several issues. To illustrate, the first participant clarified how her supervisor's field knowledge expanded her horizon and satisfied her:

"Field information. Absolutely, he has the command of field information. And, he has both the command of field information and of the eee research well research traditions. Namely, what we mean by field information, he has the command of courses, topic in the field of applied linguistics. As I said, I learned from him whatever I learned on how to research, how to publish to broaden my horizon. Plus, that is to say, I think that he is pretty competent in field information." (Seyma, female, PhD, 17 January 2018)

Besides, the participants were found happy with good communication with their supervisors. They reported that their supervisors were accessible all the time and they could ask for their expert opinion whenever and wherever they wanted. The following excerpt exemplifies the good communication between students and supervisors:

"Absolutely, I am satisfied with his communication very much. There is no time limitation anyway of my advisor. He is a well someone who can be accessible well at all hours. At least, this is true of me. I do not know for others. However, eee, for me, any moment that I want including weekend, evenings, when a problem occurred, when ee I asked, he gives answers all my works that I did. I am satisfied with him." (Yusuf, male, MA, 7 March 2018)

The participants were also found satisfied with personal qualities of their supervisors, for they described them as students-friendly, encouraging, understandable, kind, careful, and encouraging. To illustrate, the following participant expressed how encouraging her supervisor was and appreciated whatever she did in the programme:

"Eee now, I did masters' and doctorate here. Ee, I studied with the same advisor in both. When I generally considered I was satisfied with my advisor. Why was I satisfied? Ee, my advisor has a broad ee vision, he encouraged me consistently in terms of academic works. He appreciated what I did. You know, he encouraged me in respect of publishing consistently. Indeed, I was satisfied with him in this sense. I learned things on research from my advisor. To tell the truth, as I think that he was one of the best of program I am generally satisfied with my advisor. " (Seyma, female, PhD, 17 January 2018) 
Although satisfaction with supervisors is high, based on their supervision experience three participants complained about the busy schedules of their supervisors, which result in less time spent for each students and insufficient feedback. This may result from the fact that the academic staff is limited although the programme accepts approximately 10 new students each year. Lecturers have to supervise more than ten students altogether, and this automatically decreases the quality of time the two parties spend together. For instance, the following excerpt shows that as supervisors are responsible for guiding so many students simultaneously, they cannot allocate enough time for each, and thus the students cannot get enough feedback about their academic products:

"There were some points that I was not satisfied with. That is to say, since my advisor was very busy, for instance, umm time, he was limiting the time that he would allocate me. Maybe he had to do so or he trusted my competences, namely, he was setting me free. If I had kept order, this might have caused procrastination. But, what happened, I could manage the process thanks to my competences. In another words, one biggest complaint of mine is that my advisor could not allocate me enough time." (Seyma, female, $\mathrm{PhD}, 17$ January 2018)

The picture about programme instructors is almost the same in that almost all were found satisfied with the academic staff. While the positive codes about instructors are 56 , the negative ones are 17. Similar to supervisors, the academic staff was found really sincere and friendly $(n=8)$ and quite competent in their fields $(n=15)$, thereby equipping students academically well in a friendly atmosphere. They were praised to have good communication with their students $(n=9)$, to adopt positive attitudes towards students $(n=5)$, to have pedagogical competence $(n=4)$, to share their sources with students $(n=2)$, to be accessible $(n=2)$, and to encourage students $(n=2)$. The following two excerpts exemplify two common aspects that the students were happy with, i.e., good communication and field expertise:

"In the class and out, I saw, namely, other universities. I had been in ee many universities. I took courses. Well, that is to say, I mean, the environment in KTU is friendlier. There is a very close relationship between lecturers and students here. Ee, I mean, within affection and respect without crossing the line, to me it should be so, and there is a friendly relationship between lecturers and students. Let's say friendship. Namely, it goes beyond sometimes. I mean, it sometimes becomes just like brotherhood beyond friendship for us. I mean, I like this very much, this condition." (Hayri, male, PhD, 17 February2018) 
"Their pedagogical competences are pretty good. That is to say, as I said, I learned from them whatever I learned. Their materials, rich methods are suitable for critical thinking. They are the characters who offer you every kind of opportunity to stand on your legs by yourself in an independent way in this world, I mean academic world, to widen your horizon and to publish." (Seyma, female, $\mathrm{PhD}, 17$ January 2018)

Despite several strenghts of the programme, the participants self-reported some negative aspects: lecturers extending class time $(n=4)$, assigning students with heavy course loads $(n=3)$, lacking expertise in various fields $(n=3)$, lacking experience $(n=3)$, providing inadequate feedback for student assignments $(n=1)$, having poor communication with students $(n=1)$, and not encouraging them about academic career $(n=1)$. The former two codes should be interpreted with caution in that these points cannot be interpreted as negative ones solely by looking at self-reports. As the programme administration has high expectations of the programme, the lecturers may need to extend course duration which is 90 minutes to keep up with the heavy course load and schedule.

The results that show that participants openly expressed how content they were with their supervisors and academic staff prove that education quality is more influential agent towards students' satisfaction than service quality. This finding is tandem with the ones of Osman, Saputra and Saha (2017), who found a direct relationship between student satisfaction and programme quality. They concluded that program quality covering academic factor, curriculum, and teaching methods is vital in the sense that students tend to associate it with reputation and more job opportunities. These two apply to Turkish education context as universities are the prime requirements for job placement in Turkey. These also support the findings of Ekinci and Burgaz (2007) in that their participants found academic services and relations very important. They were really happy with their supervisors, which may show that academic supervisors do things appropriately and on time. However, in the current study although the participants were happy with expertise of and good relationships with their supervisors, they complained how they spent insufficient time and they could not provide timely feedback. This could be explained with the high number of students per advisor. Besides, they found that their participants were less satisfied with the academic guidance of their supervisors about career prospects after graduation, which should be interpreted as high future anxiety. However, in the current study future anxiety was not identified, which may result from the fact that the MA and $\mathrm{PhD}$ candidates are well equipped with abilities to make themselves heard in the academic world and provided chances to express 
themselves in conferences and articles during their education. Some lecturers also require them to publish as course requirement, which all inform the candidates about future career prospects. The findings of the current study are also in line with those of Elliot and Healy (2011), who found that academic consultancy and educational adequacy, i.e., instructional effectiveness, influence satisfaction degree of attendees much. Similarly, the results support those of Erichsen, Bolliger and Halupa (2014), who found that majority of the trainees were satisfied with their mentors thanks to their characteristics of being communicable, friendly, cooperative, respectful, expert in their fields and willing to allocate time for consultation and feedback. Similar to the current study, they also found that some complained about their supervisors as they were incommunicable, distanced, inexpert in their practice, inadequate in supporting feedback and time, and it was difficult for them to change their supervisors.

The participants were found highly satisfied about programme curriculum and course contents (42 positive and 5 negative related codes). They openly reported their satisfaction as the programme staff is transparent in that they inform them about the course syllabus at the very beginning of the term $(n=13)$, and the course syllabuses are carefully followed $(n=9)$. They also reported that the programme provides course variety $(n=6)$, courses cover current issues $(n=4)$, and course contents are relevant to the field $(n=3)$. They were also found happy to have been offered elective courses and those about sub-disciplines $(n=2)$. They also stated that recent articles were read and analysed in the course $(n=2)$, and their awareness increased with interesting, high-level, and serious topics. For instance, the following excerpt illustrates how courses attracted their attention and encouraged them to analyse, synthesise, and make inferences:

"Course contents were very crashing and effective. Without focusing on only one source, we had lessons focusing on research and exploring. Theory knowledge was not provided readily available. We reached this knowledge by ourselves and in the process of application we made them more strengthened. Thus, I am very satisfied." (Zennure, female, $\mathrm{PhD}, 17$ May 2018)

On the other hand, four participants complained that the programme still needs to cover various applied linguistics courses, and the course contents should be enriched. The point to be made here is that there is still plenty of room for further improvement in the programme as it lacks variety at academic staff and thus course level. 
The participants were all found positive about teaching methods and techniques used by the academic staff in the programme. They reported that these techniques of their instructors providede theme good examples as they are directly applicable in their own classes $(n=7)$. They said that they loved the discussion technique $(n=6)$, which stimulated student participation and interaction. They also expressed how much they loved these student-oriented techniques that encouraged active learning. They found these techniques appropriate for the academic world and useful to contribute to their self-confidence and academic career development:

"Oh! Method and technique! As we learn consciously, let's say, we study more. Well, the method here is mostly oriented to student. Since, students make presentation, students do research ee, for instance our lecturers let us make presentations. Every week, one talks about a chapter, for instance, or we start a research paper in the class. At first, proposal later on, we go on writing introduction, literature review. I mean, it is applied as it has the name applied linguistics program. We do it in an applied way. I am pretty satisfied. You can already watch things on the internet via videos or read them on books that instructors lecture, they are the same. Here, in an applied way, instructor guide us like a supervisor. We try to learn consciously by ourselves." (Hayri, male, $\mathrm{PhD}, 26$ February 2018)

Although most participants were satisfied with their supervisors, lecturers, programme curriculum and course content, the content analysis brought several complaints about assessment and evaluation. The ones who were dissatisfied with assessment and evaluation are almost equal to those positive ones as is seen in the following table:

Table 3

Encoded Participant Comments on Assessment and Evaluation

\begin{tabular}{llll}
\hline Satisfaction & f & Dissatisfaction & f \\
\hline Having fair assessment & 9 & Having unfair exam assessment for some & 7 \\
courses & & Not benefiting from multiple-choice exam & 2 \\
Benefiting from alternative assessment & 8 & & \\
$\begin{array}{l}\text { techniques } \\
\text { Making use of paper writing }\end{array}$ & 2 & Undertaking over course-load for scoring & 2 \\
$\begin{array}{l}\text { Utilizing pen and paper exam } \\
\text { Benefiting from reading to get knowledge }\end{array}$ & 2 & Facing with unfamiliar topics in exam & 2 \\
\end{tabular}




\begin{tabular}{|c|c|c|c|}
\hline Satisfaction & $\mathrm{f}$ & Dissatisfaction & $\mathrm{f}$ \\
\hline Getting high marks from instructors & 1 & Forgetting things due to fill in the blank exam & 1 \\
\hline Benefiting from proposal writing & 1 & Ignoring general performance & 1 \\
\hline \multirow{4}{*}{$\begin{array}{l}\text { Taking advantage of techniques to help } \\
\text { article writing and publishing }\end{array}$} & 1 & Getting shocked with unexpected exam result & 1 \\
\hline & & $\begin{array}{l}\text { Having make-up exam in spite of working } \\
\text { hard }\end{array}$ & 1 \\
\hline & & Not getting what they really deserve in exams & 1 \\
\hline & & Taking exams in a short time & 1 \\
\hline \multirow[t]{2}{*}{ TOTAL } & 25 & & 21 \\
\hline & 54.34 & & 45.65 \\
\hline
\end{tabular}

As is seen in the table above, 9 participants were found happy with assessment and found testing fair. It also seems that the participants appreciated the use of alternative assessment techniques rather than solely using traditional pen and pencil exams $(n=8)$. The following female participant listed several testing techniques employed in the programme and said how appropriate these were for graduate education:

"It is a good question now. Normally, there are not many such exams called pen and paper as we know traditional pen and pencil. What is then? Well, you take courses all along the semester. You read, your instructor gives you tasks during the semester or in the semester. You carry out those tasks. For instance, they may be observation, paper writing, proposal writing, or some instructors say that you will attend at least one conference to pass this course or you will write a full paper or so on. I mean, there is not traditional pen and paper exams in this department. There is alternative assessment. Namely, that is to say, preparing well, presenting we made many presentations. Accordingly, I am quite satisfied, it should be like this." (Seyma, female, PhD, 17 January 2018)

However, the number of dissatisfied ones with the testing system is almost equal $(n=7)$ as they found exam results unfair. Besides, the programme utilises alternative assessment techniques such as open book exams, take home exams, portfolios and etc, and two were found unhappy with this as they openly voiced their wish for multiple-choice written exams. This wish may result from the fact that students are mostly familiar with this testing technique as the centrally structured Turkish education system evaluates student success with multiple choice exams. Two also found course load really heavy and complained that they had serious responsibilities to pass courses. To illustrate, the following excerpt states how unhappy she was as average matters most in admission to $\mathrm{PhD}$ programmes: 
"Here, that is the point I am not satisfied with. To me, I can tell I am satisfied with given education. However, assessment and evaluation, namely, we are master students. To tell the truth, I come here from a different department, too, I studied very much, I believe that I focused on my works. But, in a word, the marks I got made me upset. Okay, marks are not important; however, namely, I put my efforts and you do homework, in return, how I should know. Yes, the marks I got sometimes made me upset at the same time, namely, or if you ask our instructors, they will state that marks maybe are not important. But, you are required to get an average to enter PhD program. Well, for instance in some classes, well I actually do not tell this for all, well, I got the good marks in the classes I did homework. In a class, something happened, namely, ah, right I did this, I did this too, I did, yet the mark is CB that well makes me upset." (Zilan, female, MA, 7 March 2018)

Similarly, in the following excerpt the participant told an experience in which he got a very low mark despite much effort; however, in another one, he got the highest mark although he did not do much. He showed how perplexed he was about these two testing experiences as he could not understand the criteria used to test his knowledge and evaluate his effort:

"Do I consider it fair? Ee, ah, to me ee, for instance something happened like this. I laughed at that very much. I took a course from LI in the first semester. Ee, it was like well, it was well like this. Even, well, he himself brought me a book when I was in a different course. We were in old building then, ee, namely, it is going well, he said that let's make this a paper so-and-so. Later, it was going well. Then, it was semester vacation so-and-so, but you know there is not a thing namely such a thing like break. You go on, you go on. Later on, now, I looked that the instructor gave me CC. Again, in the second semester, I took a different course. This time, I did not put much effort. It was normal, I got AA, now, this time I felt well, let's not say unfair to that ee or let's not say unfair, but I felt a contradiction. In a word, there is a parameter that I do not understand. Well, one waits, you say that this work is very good. Let's make it a paper and present it in the conference so forth. Eyou say that things are going well you get CC. This time, you get AA from the work he did not tell a positive thing. I wonder whether he confused courses or students, namely let's not say unfair, but ee just like a little consistent, maybe consistent is not a correct word. However, well, I got a result that I did not expect." (Umut, male, MA, 19 March 2018)

It is clearly seen that fair testing and evaluation is one of the main factors that ensures programme satisfaction and advisability. These findings about assessment and evaluation are in line with those of Ekinci and Burgaz (2007), who reported that their respondents cared about fair evaluation of exams, projects, other tasks, and quality of activities in the course that would contribute to their achievement. They rightly concluded that students have high expectations of fair assessment and evaluation. Similarly, the participants in the current study were found 
highly sensitive about appropriate and fair evaluation of their work as everybody naturally wants good conclusions about what they have done in a process. Also similar to the study of Kaya and Engin (2007), some participants were found dissatisfied with assessment and evaluation of their exam results. A possible explanation for this finding is that the participants in both studies were unhappy as the assessment criteria were not shared with them. This may affect them negatively in that their anxiety increases and their motivation to study and learn more decreases. In line with what they suggest, the participants in the current study voiced their wish for improvement of correlation between course content and assessment and transparency about assessment and evaluation.

Another aspect of education quality is learning climate. The participants were found satisfied with it in that there were more positive codes than the negative ones $(30 ; 6$, respectively). The classroom environment was found warm $(n=9)$ as there was good friendship among peers $(n=3)$, and the sparsely populated classrooms $(n=4)$ enabled good peer to peer interaction $(n=3)$. However, one participant found the learning climate stressful particularly when MA and PhD students took common classes. And one voted for more flexible environments as the existing ones are sometimes boring. The following excerpt illustrates the general attitude towards classroom climate:

\begin{abstract}
"Well, this program necessarily includes class that has few students utmost 5, 6, or 7 students. And, graduate education is always paid great importance in this department. The best classes were allocated for them. They were given priority. The best place was allocated for them. The classes were equipped technologically. For instance, there is projection. Accordingly, communication among peers is very good. For example, such well, you know, we are an eastern community. There is a strict relationship between teacher and students. Normally, it should be like that. But, it is not the same in doctorate education or masters' education. You are more sincere. As the occasion arises, you can have incentives. For instance, your lecturer can offer you chocolate, coffee or he can say that let's go to the canteen, he can say that let's have lunch in that cafe. When I think generally, I put them all in concept of classroom climate. And, I am pretty satisfied." (Seyma, female, PhD, 17 January 2018)
\end{abstract}

The last element of education quality is academic attainments. Almost all the participants were found quite content with the academic attainments of the programme. They reported that the programme taught them how to research $(n=13)$, enhanced their oral presentation skills $(n=11)$, taught them how to write academic articles $(n=11)$, fostered their academic language and awareness $(n=5)$, instructed them about how to read and interpret scholarly journal articles 
$(n=4)$, enabled them to practise language $(n=3)$, provided opportunities to present in conferences $(n=2)$, taught them how to research and publish in prestigious journals $(n=3)$, and helped them gain new insights in language teaching $(n=2)$. Yet, two complained that the programme did not improve their language skills enough and not encourage them to produce academically. In the following excerpt, the participant reported how this graduate education helped him make his voice heard in the academic platforms by producing academically:

"Research abilities. We learned what research is, what to do from the beginning. We researched ee especially in research classes. Well, we wrote proposals, we wrote articles. For instance, as I said, I attended two conferences there are things of them. Well, I have 3 published articles in total until now. Well, I carried out them with things that I attained here, I mean, with the supports of instructors, thanks to feedback of them. I mean I published by studying ee with instructors. " (Cetin, male, MA, 26 February 2018)

The results show that most of the participants were content with the programme's academic attainments as it helped them improve professionally and made their voice heard in the academic arena thanks to conferences and academic articles. Many of the students were found to utilise the classes on research; however, this finding is contrary to those of Hernández (2009) in that it was seen that knowledge on research method was not greatly benefited by the participants in that study. A possible explanation for this is that the graduates in their study mostly work as teachers, and they cannot or do not want to apply research methods at their job and do not see research as their main duty. However, in the current study one of the ultimate aims of the programme is to equip students well regarding theory and academic productions, and the students regard conducting systematic scientific research and publishing in scholarly journals as their main responsibility in their job. Y1lmaz et al. (2017) also found that MA students did not gain academic attainments as doctoral students did. Similarly, in the current study $\mathrm{PhD}$ students seem to have obtained more attainments in the program compared to those of MA students. This might result from the fact that the ability to conduct scholarly research is gained in time, and as MA students in the current programme are at the very beginning of their academic journey and not well-equipped with publication skills yet, they generally try to get as much as theoretical information, and in $\mathrm{PhD}$ they transfer whatever they have learned into practice and start to produce academically. 


\section{Satisfaction with Service Quality}

In addition to education quality, students' satisfaction with service quality was also investigated in the current study. Service quality should be understood as administrative services and physical facilities. The related findings are presented one by one below.

While 22 positive codes were created about administrative services, 9 negative ones were identified. The participants were satisfied with getting answers for their questions by Social Educational Institution ( $\mathrm{n}=5)$, gaining required support in academic, registration, and technique terms $(n=4)$, getting good service by departmental administration $(n=3)$, being treated well by the departmental administration $(n=3)$, having easy communication with them $(n=1)$, having student-friendly and smiling staff ( $\mathrm{n}=1$ for each), and adopting an open-minded and innovatory management $(n=1)$. However, three participants complained about the careless/too many procedural steps by Social Educational Institute $(n=3)$, strict attitude by Social Education Institute $(n=2)$, quite strict thesis writing guide $(n=2)$, delayed announcement by the departmental administration $(n=1)$, and the difficulty in reaching Social Educational Institute by phone $(n=1)$. To illustrate, the following excerpt shows how hard the head of the department worked and how students appreciated his administrative efforts:

"The manager of program, the coordinator of masters' program is (...), but our head of department is (...) as he is the head of Western Language and Literature. (...), pretty how to say, works like a municipality. He works like an atom ant. He provides his support for everyone in everywhere. He organizes everything in a good way. He coordinates. I am pretty satisfied. Amongst these, organizing lecturers, courses, I mean, he even gives an idea that where a chain should be placed in any case. That is to say, I can say that he keeps alive the department." (Hayri, male, MA, 26 February 2018)

When the answers about the physical facilities were analysed, it was seen that the picture is almost the same in that most were found content with these services. While the positive codes are 78, the negative ones are 33. The participants were found satisfied due to clean classrooms $(n=16)$, good Internet connection $(n=9)$, good security service $(n=8)$, technologically wellequipped classrooms $(n=7)$, easy transportation $(n=7)$, good library loan service and offcampus service $(n=6)$, rich online library service $(n=5)$, satisfactory canteen service with food variety and friendly staff $(\mathrm{n}=11)$, and good heating $(\mathrm{n}=1)$. On the other hand, some complaints were identified: lack of financial assistance for academic attempts $(n=7)$, entrance fee to 
campus $(n=4)$, poor security service $(n=5)$, poor transportation service $(n=3)$, problems with Internet connection $(n=4)$, lack of a departmental library $(n=2)$, hygiene problem with canteen service $(n=2)$, poor library sources $(n=2)$, lack of support for accommodation $(n=1)$, poor food quality in the canteen $(n=1)$, crowded and small central library $(n=1)$, and unclean classrooms $(n=1)$. To illustrate, in the following excerpt the participant expressed how online library services and off-campus connection helped him reach sources easily:

"Let's say that there is no printed book anymore. We use online library anymore. To me, (...) University is very good. We have plenty of online library, online data base. When we entered well into catalogue page or well into online library, I mean, there is almost nothing you cannot find that you look for. That is to say, we can find thousands of articles, thesis, well, book. I mean, you can access and down load these in the event that you have internet connection of university or use off-campus access when you are out without any trouble." (Hayri, male, MA, 26 February 2018)

However, the following excerpt exemplifies how students were unhappy as they were not supported financially by the programme as the participant needed to pay all his expenses on his own although what he did all contributed to the academic prestige of the institution:

"Whereas, when a student attends again on behalf of (...), you represent (...)there, as I said the name of (...)is mentioned in your article ee in the full text article; however, there is no support related to this. I went to Vienne and came. Later, again I went to Rome last year. I went to Italy, there were expenses nearly 3000 Turkish liras that was paid from my pocket. I did not take any financial assistance either from school or from others, but only with my family's support simply because to get certificate and to have a published article. Ee later, I went to Ordu, it was an international conference, it was cheaper in Ordu, but I paid about 500 liras from my pocket. When you save all these, now, I have paid ee about 6 thousand or 7 thousand from my pocket for conferences in two years. The name of (...) was included in all, ee we increased the thing, I mean, it increases ee academic level recognisability, whatever it is, we increased its rank. But, I have not even taken any financial assistance from (...)until now.” (Cetin, male, MA, 26 February 2018)

Poor library service and lack of financial support were also found as two aspects that decrease student satisfaction with the programme in the recent study of Al-Dulaimi (2016). Also the satisfaction with the administrative staff was also identified in earlier studies (see for instance, Özçetin \& Gök, 2017). On the other hand, student satisfaction with service quality is contrary to the results of Okumuş and Duygun (2008), who found that the participants were unsatisfied with physical facilities such as efficiency of materials employed in the class, cleaning of 
classes, course surroundings, and modern appearance of the department. High satisfaction with the physical facilities in the current programme could be associated with the fact that the administration attaches great importance to the quality of the graduate programme and allocate resources for it. Besides, the building where the graduate education is offered is the newest building of the campus, and therefore it is natural to be clean and modern.

\section{Self-reported Suggestions to Improve the Programme}

The participants were also asked to provide their suggestions to improve both education and service quality of the programme. Their suggestions are listed in the following table:

Table 4

Participants'Suggestions for Programme Improvement

\begin{tabular}{|c|c|}
\hline Participant Suggestions & $\mathrm{n}$ \\
\hline Offering accommodation service & 8 \\
\hline Inviting guest lecturers in different fields & 3 \\
\hline Employing more instructors expertising in various fields & 2 \\
\hline Offering rubric for assessment and evaluation & 2 \\
\hline Increasing field sources in library & 2 \\
\hline Assigning supervisors with fewer students & 1 \\
\hline Offering more careful supervision services & 1 \\
\hline Providing a more flexible thesis writing guide by Social Education Institution & 1 \\
\hline Offering stronger and more effective advising service & 1 \\
\hline Supervising students about steps of thesis writing well & 1 \\
\hline Studying more practical issues in language teaching & 1 \\
\hline Accepting fewer students for graduation program to spare quality time & 1 \\
\hline Providing more flexible schedule & 1 \\
\hline Offering courses related to ELT & 1 \\
\hline Sharing syllabus with students & 1 \\
\hline Speaking English rather Turkish in classrooms & 1 \\
\hline Encouraging students with financial aid for academic works & 1 \\
\hline Allocating office for students & 1 \\
\hline Adding elective course & 1 \\
\hline Investigating the reasons for dropping out the program & 1 \\
\hline Improving good communication between lecturers and students & 1 \\
\hline Providing clear announcement on web-site by Social Education Institution & 1 \\
\hline
\end{tabular}




\begin{tabular}{ll}
\hline Participant Suggestions & $\mathrm{n}$ \\
\hline Serving updated information on departmental web-site & 1 \\
Equipping library with enough computers & 1 \\
Holding student festivals for recognisability & 1 \\
Preparing weekly language magazine & 1 \\
Providing self-service food in canteen & 1 \\
Offering more understanding management service & 1 \\
\hline
\end{tabular}

One of thee suggestion was to add variety to courses the programme offers by increasing the number of lecturers expertising in various fields:

“(...) but as I said before, if diversity in instructors can be provided, course curriculum automatically will become verified, too. To illustrate, for instance, I have graduated from here. I had my doctorate degree from here, for instance, I study in the field of English as an international language or English as a lingua franca. For instance, I do not see why not such a course is offered here. If I were an instructor here, this course automatically would be offered. For example, we have an instructor here graduated from this program; his field is corpus, well corpus. Accordingly, when this instructor is accepted to the program, corpus course will be offered right away. What does it show? Just as diversity in instructors increases so the richness of course curriculum increases." (Seyma, female, $\mathrm{PhD}$, 17 January 2018)

In addition to course variety, one common complain about the programme was the busy schedules of the supervisors, which hindered them from providing effective feedback and dealing with students individually and carefully:

"Oh! A better way, I feel lack of, well, namely to me, now we will go on the stage of thesis writing. I think that we are not guided for thesis writing process well. It is as if they wanted us to research and find on our own. I wish that they show us one by one. You will start just like this and you will go on like this, and so on. Apart from this, I wish to have opportunity to meet with advisors one by one. That is to say, both we do not have time and instructors do not have, too. I wish to have one by one meeting." (Umut, male, MA, 19 March 2018)

\section{Overall Satisfaction and Programme Advisability}

The participants were also asked whether they would suggest the programme for new candidates to investigate the advisability of the programme. 3 of them certainly advised the $\mathrm{PhD}$ programme for the opportunity of overseas study, collaboration with recognizable and 
prestigious universities, and academic staff with field and pedagogical knowledge. 3 recommended the $\mathrm{PhD}$ programme with the condition that the newcomers should spend much time and effort on their classes, get used to heavy course load and busy schedule, and take the programme seriously. Similarly, while 4 recommended the MA programme for the newcomers, 8 advised it on the condition that students should be ready for heavy course load.

Lastly, the participants were asked to score the programme out of 10 . The median score was 7.4, which should be understood that the participants were fairly satisfied with the programme mostly due to high education quality. Yet, it was seen that there is much room for improvements regarding supervision, schedules, assessment and evaluation, and financial support.

\section{Conclusion}

The aim of this exploratory case study is to find out the satisfaction level of $\mathrm{MA}$ and $\mathrm{PhD}$ students' enrolled at the Applied Linguistics programme of a public higher education institution in Turkey. The findings show that education quality was found as an influential agent in student satisfaction. The participants valued the field knowledge of both their supervisors and lecturers and appreciated their attempts to direct their academic works. In another words, they seemed to value the academic staff having a sound knowledge of academic issues. They openly stated how happy they were as this knowledge enables them to make their voice heard in the academic arena by presenting in conferences and publishing in scholarly journals. Yet, the participants complained about the busy schedules of their supervisors as they cannot spend enough time for them. As Phillips and Pugh (2010) observe, students expect their supervisors carefully read their works, write comment on them, and make an overall evaluation, and if they cannot get this attention, bad feeling and communication breakdown are indispensable. Therefore, it is of utmost importance to assign fewer students to each supervisor in such programmes to ensure healthy $\mathrm{MA}$ and $\mathrm{PhD}$ supervision process with effective feedback sessions, which could bring about high quality academic attainments. However, unfortunately the number of MA and $\mathrm{PhD}$ students is really high in Turkish universities, and it may not be possible for advisors to offer individual care. Here, increasing student autonomy and equipping them well with academic strategies including time management could serve well to boost student independence. Such self-sufficient students may help themselves to learn 
independently, their peers to conduct fruitful tasks, and their advisors to save much time. Besides, peer coaching could be encouraged in that more experienced and proficient students could lead small groups, guide them, analyse their needs, and may report back to their advisors. As Phillips and Pugh (2010) rightly note, the attempts of giving effective feedback are vital, for this process help them "eventually learn how to evaluate their own work and so take over this part of the supervisor's job themselves", and "In the longer term, they have to be taught how to become independent researchers in their own right” (Phillips \& Pugh, 2010, p. 158). Although the existing lecturers were highly appreciated, the findings show that the number of academic staff should be increased to ensure course variety, better consultancy services and high-quality time allocated for students, which all could promote university rank and prestige.

It is also seen that they value their relationship with their supervisors and lecturers, in that the friendly communication and easy access to them encourage them and earn the sense of programme ownership. Having good communicative skills is one of them most desired socioaffective skills for effective language educators and supervisors, and they are expected to have the personality traits of being understanding, open, supportive, caring and loving, motivating, and friendly (Erbay, Erdem, \& Sağlamel, 2014; Phillips \& Pugh, 2010). Thus, as Phillips and Pugh (2010) rightly put, an effective supervisor should not only deal with academic issues but also evaluate their relationship with their students and attempt to find ways to better it.

However, one of the most commonly criticised points is assessment. The ones who are satisfied and dissatisfied with assessment and evaluation were found almost equal. They complained that the lecturers should be transparent about their rubrics and evaluation criteria. Also it was seen that they are not happy as they cannot get whatever they deserved no matter how hard they try sometimes. Therefore, it is of utmost importance to announce scoring rubrics and criteria and their justification at the very beginning of course or any performance and to be open about all requirements. Similarly, Brown (2004) suggests that all grading criteria about the final grade "need to be explicitly stated in writing to students at the beginning of the term of study, with a designation of percentages or weighting figures for each component” (p. 285, emphasis in original). This transparency, i.e., student awareness about the reasons why these are set, is vital to motivate student learning (Jonsson, 2014). Besides, it could be practical to use alternatives in assessment, i.e., triangulation, in that only formal tests cannot serve well to "capture the totality of students' competence", and thus techniques beyond tests including 
portfolios, journals, conference and interviews, observations, and self and peer-assessments could be utilised (Brown, 2004, p. 284).

As indicated by the findings, some graduate students grumbled about heavy course load. Seeing that they have to travel from different cities to their school every week and have both professional and familial responsibilities, a more flexible program might be created. Here distance education could be suggested for those who come from distance provinces.

In addition to education quality, service quality was also found satisfying by the participants. Yet, lack of a departmental library seems to bother them much. Thus, it could be better to design a library full with related academic sources at the department as library services contribute to student satisfaction in a positive way (Erdoğan \& Bulut, 2015). Here academic staff could share their sources to create a common library that can serve well for academic needs of MA and $\mathrm{PhD}$ candidates.

A note of caution is necessary that as this is a small-scale explorative case study, the findings cannot be generalised to larger settings to provide a full description of Turkish graduate education context. Besides, as the participants might feel hesitant as they could be identified and this could hamper their academic career, they might not voice their real feelings. Therefore, further studies could utilise options to avoid respondent bias, i.e., to boost the participants' willingness to give accurate answers experiences and talk about their experiences such as selfreporting, which served really well in the current study for the two participants feeling uncomfortable about being recorded. Besides, "assessment and evaluation" phenomenon was found as one of the most significant aspects to determine student satisfaction, and thus further studies could focus on this particular issue in depth. 


\section{References}

Al-Dulaimi, Z. Y. (2016). Student's satisfaction about the level of administrative and academic performance in the faculty of administration and economy Al-Iraq1a university (a survey). Business Statistics-Economic Information, 13(27), 153-164.

Altaş, D. (2006). Üniversite öğrencilerinin memnuniyet araştırması. Marmara Üniversitesi IIBBF Dergisi, 21(1), 439-458.

Alves, H., \& Raposo, M. (2007). Conceptual model of student satisfaction in higher education. Total Quality Management \& Business Excellence, 18(5), 571-588. doi:10.1080/14783360601074315

Anderson, B., Cutrihgt, M., \& Anderson, S. (2013). Academic involvement in doctoral education: Predictive value of faculty mentorship and intellectual community on doctoral education outcomes. International Journal of Doctoral Studies, 8, 195-201. doi:10.28945/1923 university education.

Athiyaman, A. (1997). Linking student satisfaction and service quality perceptions: the case of university education. European Journal of Marketing 31(7), 528-540

Ay, G., \& Koç, H. (2014). Determining the student satisfaction levels in higher education and analyzing them for certain variables an application for the students in office administration and executive assistancy program. Electronic Journal of Vocational Colleges, 122-133.

Aydemir, E. (2016). A new approach for ranking universities based on student satisfaction. Journal of Higher Education 6(3), 128-141. doi:10.2399/yod.16.011.

Batmaz, V., Öztürk, R., Vardar, Ö., Yanık, M., Yarman, S., \& Yazıc1, H. (2011). A proposal from Istanbul university for a new legislation on higher education. Journal of Higher Education, 1(1), 6-7. doi:10.2399/yod.11.006

Berg, B. L. (2004). Qualitative research methods for the social sciences (5th ed.). Boston: Pearson Education.

Blaxter, L., Hughes, C., \& Tight, M. (2006). How to research. Berkshire: Open University Press.

Bogdan, R. C. \& Biklen, S. K. (2007). Qualitative reaserch for education: An introduction to theories and methods (5th ed.). Boston, USA: Pearson Eductaion, Inc. 
Booth T. \& Booth, W. (1994). The use of depth interviewing with vulnerable subjects: Lessons from a research study of parents with learning difficulties. Social Science and Medicine, $39(3), 415-424$.

Boyce, C., \& Neale, P. (2006). Conducting in-depth interviews: A guide for designing and conducting in-depth interviews for evaluation input. Watertown, MA: Pathfinder International.

Bozan, M. (2012). Lisansüstü eğitimde nitelik arayışları. Sosyal ve Beşeri Bilimler Dergisi, 4(2), 177- 187.

Bright, L., \& Graham, C. B. (2016). Predictors of graduate student satisfaction in public administration programs. Journal of Public Affairs Education, 22(1), 17-34.

Brown, H. D. (2004). Language assessment: Principles and classroom practices. New York, NY: Pearson Education.

Bryman, A. (2004). Social research methods (2nd ed.). New York: Oxford University Press.

Chumney, C. G., \& Ragucci, K. R. (2006). Student satisfaction and academic performance in dual PharmD/MBA degree program. American Journal of Pharmaceutical Education, 70(2), 1-4.

Cohen, L., Manion, L., \& Morrison, K. (2007). Research methods in education (6th ed.). London: Routledge Falmer.

Creswell, J. W. (2007). Qualitative inquiry and research design: Choosing among five approaches (2nd ed.). Thousands Oaks: Sage Publications, Inc.

Denscombe, M. (2010). Ground rules for social research: Guidelines for good practice. (2nd ed.) Maidenhead: Open University Press.

Durmaz, Ş. (2011). Qafqaz Üniversite öğrencilerinin üniversitede beğendikleri yönlere ilişkin değerlendirmeleri. Journal of Qafqaz University Economics and Administration, 31, 30-36.

Ekinci, E., \& Burgaz, B. (2007). The expectation and satisfaction levels of the students at Hacettepe University with respect to academic services. H. U. Journal of Education $33,120-134$.

Elo, S. \& Kyngas, H. (2008). The qualitative content analysis process. Leading Global Nursing Research. doi.org/10.1111/j.1365-2648.2007.x. 
Elliott, K. M., \& Healy, M. A. (2001). Key factors influencing student satisfaction related to recruitment and retention. Journal of Marketing for Higher Education, 10(4), 1-11. doi:10.1300/j050v10n04_01

Elmir R., Schmied V., Jackson D., \& Wilkes (2011). Interviewing people about potentially sensitive topics. Nurse Researcher, 19(1), 12-16.

Erbay, Ş , Erdem, E , Sağlamel, H . (2014). The portrait of a good foreign language teacher: A cross-interview analysis of private language course administrators' opinions. Turkish Online Journal of Qualitative Inquiry, 5 (4), 41-61.

Erdem, A. R. (2013). Changing roles and missions of university in information society. Journal of Higher Education 3(2), 109-120. doi:10.2399/yod.13.013

Erdoğan, E., \& Bulut, E. (2015). Investigation of factors affect satisfaction levels of business students'. Journal of Management Economics and Business, 2(26), 151-170. doi: org/10.17130/ijmeb.2015.11.26.907

Erichsen, E. A., Bolliger, D. U., \& Halupa, C. (2014). Student satisfaction with graduate supervision in doctoral programs primarily delivered in distance education settings. Studies in Higher Education, 39(2), 321-338. doi.org/10.1080/03075079.2012.709496.

Ersoy, A. (2015). Investigation of $\mathrm{PhD}$ students' initial qualitative research experiences via their diaries. Journal of Education and Instruction, 5(5), 549-568. doi: 10.14527/pegegog.2015.030

Giese, J. L. \& Cote, J. A. (2002). Defining consumer satisfaction. Academy of Marketing Science Review, 2000(1).

Giorgetti, F. M. (2014). Doktora Eğitiminin Tarihi, Felsefesi ve Ritüelleri: Ístanbul Üniversitesi Örneği [PowerPoint slides]. Retrieved from file:///C:/Users/dell/Desktop/Doktora-Eğitiminin- Tarihi-Felsefesi-ve-Ritüelleriİstanbul-Üniversitesi-Örneği.

Gocer, A. (2010). A qualitative research on the teaching strategies and class applications of the high School teachers who teach English in Turkey as a foreign language. Education, 131(1), 196- 210.

Göksu, G. G. (2015). Yükseköğretim finansmanı kapsamında yaşanan değişimlerin ve yeniliklerin analizi. SA ̈̈ Ĕ̈itim Bilimleri Enstitüsü. Sakarya.

Hahessy, S., Burke, E., Byrne, E., Farrelly, F., Kelly., M., Mooney, B., \& Meskell, P. (2014). Indicators of student satisfaction in postgraduate blended learning programmes: Key 
messages from a survey study. The all Ireland Journal of Teaching \& Learning in Higher Education, 6 (3), 1941-19423.

Hernández, M. S. (2009). Graduates' degree of satisfaction with the MA program in teaching English as foreign language at the University of Costa Rica. Revista de Lenguas Modernas, 10, 373-392.

İçli, G. (2001). Eğitim, istihdam ve teknoloji. PamukkaleÜniversitesi Eğitim Fakültesi Dergisi, 9, 65- 71.

Jalali, A., Islam, A., \& Ariffin, K. H. K. (2011). Service satisfaction: The case of a higher learning institution in Malaysia. International Education Studies, 4(1), 182-192.

Jonsson, A. (2014). Rubrics as a way of providing transparency in assessment. Assessment \& Evaluation in Higher Education, 39 (7), 840-852. doi: 10.1080/02602938.2013.875117.

Kara Ö. T. (2017). Students' satisfaction levels of Turkish teaching program and services provided in this program in Turkish teaching department at Cukurova university. Journal of Theory and Practice in Education, 13(1), 144-157.

Karakütük, K. (1989). Türkiye'de lisansüstü öğretim, sorunları ve çözüm önerileri. Ankara Üniversitesi Eğitim Bilimleri Fakültesi Dergisi, 22(1), 505-528. doi: 10.1501/Egifak_0000000881.

Kashan, A. (2012). Measuring Student Satisfaction of Master Level Students; Evidence from University of Sargodha, Pakistan. School of Doctoral Studies (European Union) Journal, 216-222.

Kaya, İ., \& Engin, O. (2007). A research on measuring student satisfaction level for quality of education improving in higher education system. Journal of Education and Social Sciences, 174, 106-115.

Koğar, H., \& Sayın, A. (2014). Analysis in the accuracy of classification in students' graduate school entrance. Ankara University, Journal of Faculty of Educational Sciences, 47(1), 171-186. doi: 10.1501/Egifak_0000001322

Koshkin, A. P., Rassolov, I. M., \& Novikov, A. V. (2017). Monitoring social media: Students satisfaction with university administration activities. Education and Information Technologies, 22(5), 2499-2522. doi:10.1007/s10639-016-9558-x

Kotler, P. \& Keller, K. L. (2012). Marketing Management (14th ed.).Boston: Prentice Hall.

Macnamara, J. (2005). Media content analysis: Its uses, benefits and best practice methodology. Asia Pacific Public Relations Journal, 6(1), 1-34. 
Mai, L. (2005). A comparative study between UK and US: The satisfaction satisfaction in higher Education and its influential factors. Journal of Marketing Management, 21, 859-878.

Mehdipour, Y. \& Zerehkafi, H. (2013). Student satisfaciton at Osmania University. International Journal of Advancements in Research \& Technology, 2(6), 233-240.

Moses, L. W. (2008). Satisfaciton among current doctoral students in special education. Remedial and Special Education, 29(5), 259-268. doi:10.1177/0741932507312014

Mwiya, B., Bwalya, J., Siachinji, B., Sikombe, S., Chanda, H., \& Chawala, M. (2017). Higher education quality and student satisfaction nexus: evidence from Zambia. Creative Education, 8(7), 1044-1068. doi:10.4236/ce.2017.87076

Official Gazette (1981). Higher Education Law. (1981, 6 November).

http://www.yok.gov.tr/documents/10279/29816/2547+\%20Yükseköğretim+Kanunu/

http://www.ua.gov.tr/programlar/erasmus-program1/yükseköğretim-programı

http://yok.gov.tr/en/web/uluslararasi-iliskiler/turkiye-de-yuksekogretim-sistemi

http://www.yok.gov.tr/web/uluslararasi-iliskiler/bologna-sureci-nedir

Official Gazette (2016, 20 April). Graduate Education Law 29690. http://www.yok.gov.tr/documents/10279/23688337/lisansustu_egitim_ve_ogretim_y\%C3\%B 6netmeligi.pdf/8451c3e1-7975-40f1-bc81-3ca01cb288c8

Okumuş, A., Duygun, A. (2008). Service quality measurement on education services marketing and relationship between perceived service quality and student satisfaction. Anadolu University Journal of Social Sciences, 8(2), 17-38.

Oğuz, A. (2004), Bilgi çağında yükseköğretim programları. Milli eğitim dergisi, 164. Retrieved December, 22 , 2017. http://dhgm.meb.gov.tr/yayimlar/dergiler/Milli_Egitim_Dergisi/164/oguz.htm

Osman, A. R., Saputra, R. S., \& Saha, J. (2017). Determinants of student satisfaction in the context of higher education: A complete structural equation modelling approach. British Journal of Marketing Studies, 5(6), 1-14.

Ören, F. Ş., Y1lmaz, T. C., \& Güçlü, M. (2012). An analysis of the views of teacher candidates towards postgraduate education. Journal of Research in Education and Teaching, 1(2), 143-201.

Özçetin, S., \& Gök, R. (2017). Akdeniz üniversitesi eğitim fakültesi öğrencilerinin hizmet kalitesi ile ilgili memnuniyet düzeylerinin ölçülmesi. Journal of Educational Sciences Research, 7(1), 301-311. 
Özdelikara, A., \& Babur, S. (2016). Hemşirelik öğrencilerinin öğrenimlerine ilişkin doyum düzeyi ile etkileyen faktörler. Dokuz Eylül Üniversitesi Hemşirelik Fakültesi Elektronik Dergisi, 9(1), 2-8.

Özmen, Z. M., \& Güç, F. A. (2013). Challenges in doctoral education and coping strategies: A case study. Journal of Higher Education and Science, 3(3), 214-219. doi: 10.5961/jhes.2013.079

Öztemel, E. (2013). Building the culture of research and innovation in the higher education institutions. Journal of Higher Education 3(1), 22-29. doi:10.2399/yod.13.006.

Phillips, E. M., and Pugh, D. S. (2010). How to get a PhD: A handbook for students and their supervisors (4t ed.). Berkshire: Open University Press.

Qu, Q. S. \& Dumay, J. (2011). The qualitative research interview. Qualitative Research in Accounting \& Management, 8(3), 238-264. doi 10.1108/11766091111162070.

Queirós, A, \& Faria, D. \& Almeida, F. (2017). Strengths and limitations of qualitative and quantitave quantitative research method. European Journal of Education Studies, 3(9), 369-387. doi: 10.5281/zenodo.887089.

Serenko, A. (2010). Student satisfaction with Canadian music programmes: the application of the American customer satisfaction model in higher education. Assessment \& Evaluation in Higher Education, 36(3), 1-19. doi:10.1080/02602930903337612

Sevinç, B. (2001). Türkiye'de lisansüstü eğitim uygulamaları, sorunları ve öneriler. Ankara Üniversitesi Eğitim Bilimleri Fakültesi Dergisi, 34(1), 125-137. doi: 10.1501/Egifak_0000000052

Sümen, Ö., \& Çağlayan K. T. (2013). Prospective teachers' levels of satisfaction with schools of education and their idealized educational settings. Ondokuz Mayı Üniversitesi Ĕ̈itim Fakültesi Dergisi, 32(2), 249-272.

Şahin, A. E. (2009). Eğitim fakültesinde hizmet kalitesinin eğitim fakültesi öğrenci memnuniyet ölçeği (EF-ÖMÖ) ile değerlendirilmesi. H. Ü. Ĕ̆gitim Fakültesi Dergisi, 37, 106-122.

Tan, K. C., \& Kek, S. W. (2004). Service quality in higher education using an enhanced SERVQUAL approach. Quality in Higher Education, 10(1), 17-24. doi:10.1080/1353832242000195032

Tatl1, Z. H., Kokoç, M., \& Karal, H. (2011). Satisfaction state of computer education and instructional Technologies students: Karadeniz Technical University case. Elementary Education Online, 10(3), 836-849. 
Tekin, T. (2007). Cumhuriyet'in 100. y1lında Türk üniversitelerinden beklentiler. Ankara Üniversitesi Türk Inkılap Tarihi Enstitüsü Atatürk Yolu Dergisi, 39, 465-480. doi: 10.1501/Tite_0000000104

Theron, P. M., (2015). 'Coding and data analysis during qualitative empirical research in Practical Theology'. In die Skriflig 49(3), p. 1-9. doi. org/10.4102/ids.v49i3.1880.

Uygur, M., \& Yelken, T. Y. (2017). Analyzing the prospective primary school teachers' satisfaction level and their perception of future expectation: Mersin University sample. Journal of Higher Education, 7(1), 1-9. doi:10.2399/yod.16.006.

Varış, F. (1972). Türkiye'de lisansüstü eğitim "pozitif bilimlerin temel ve uygulamalı alanlarında”. Ankara Üniversitesi Eğitim Bilimleri Fakültesi Dergisi, 5(1), 51-74. doi: 10.1501/Egifak_0000000336

Yan, J. L. S., McCracken, N., \& Crowston, K. (2014). Semi-automatic content analysis of qualitative data. In iConference 2014 Proceedings, 1128-1132. doi:10.9776/14399

Yin, R. K. (2009). Case study research: Design and methods (4th ed.). London: Sage.

Yılmaz, A. B., Tonga, E. S., \& Çakır, H. (2017). Evaluation of graduate students' opinions about the education they receive. Gazi University Journal of Gazi Educational Faculty, $37(1), 1-45$. 